\title{
Co wspólnego ma Wniebowzięcie Marii z Ostatnią Wieczerza, czyli o genezie formy i ikonografii późnośredniowiecznego obrazu ze zbiorów Muzeum Narodowego w Poznaniu, albo o późnośredniowiecznych metodach tworzenia obrazów z użyciem grafik lub o przenikaniu sztuki Północy na Południe
}

DOI: https://doi.org/10.26881/porta.2020.19.02

Wymieniony w tytule niniejszego artykułu obraz w prosty i usankcjonowany przez tradycję sposób unaocznia obecny w Kościele od VI w. kult Wniebowzięcia Marii i przekazuje związane z nim treści (il. 1) ${ }^{1}$. Wysoce zdyscyplinowana forma podkreśla niezwykłość i powagę wyobrażonej sceny. W centrum widnieje pusty, „,uciekający” w głąb sarkofag, którego wielkość i jasnoszary kolor wyraźnie wybijają się w kompozycji dzieła. Nad nim unoszą się zwróceni ku sobie en trois quarts Maria i Chrystus. Oboje mają na głowach złote korony. Królewską godność podkreślają ponadto powłóczyste purpurowe (Maria) i bordowe (Chrystus) szaty spodnie o gęstych, sztywno załamujących się fałdach oraz obszerne, rozwiane peleryny podtrzymywane przez parę aniołów w albach - turkusowa Marii i złota o purpurowej podszewce Chrystusa. U dołu, na silnie wysuniętym do przodu cokole sarkofagu klęczy zwrócony profilem do widza modlący się apostoł, z ciemnoblond włosami i brodą, w zielonym płaszczu i purpurowej szacie spodniej. Obok niego leży otwarta księga. Przy dłuższych bokach sarkofagu zebrali się w zwartych grupach pozostali uczniowie Chrystusa. Ich fizjonomie są zróżnicowane co do typu i wieku. Wszyscy wydają się skupieni. Dwóch mężczyzn, usytuowanych w głębi naprzeciwko siebie, możemy zidentyfikować:

Nr inw. Mp 1253. Wymiary: $161 \times 114 \mathrm{~cm}$. Obraz namalowany na podłożu drewnianym. Trafił do Muzeum Mielżyńskich w Poznaniu przed 1880 r. W 1933 r. przekazano go jako depozyt do Muzeum Wielkopolskiego. W 1956 r. wpisany został do inwentarza Muzeum Narodowego w Poznaniu. Podstawowe dane inwentarzowe, techniczne i historyczne podaję za kartą katalogu naukowego w Dziale Sztuki Średniowiecznej Muzeum Narodowego w Poznaniu, założoną w 1977 r. przez Zofię Białłowicz-Krygierową. Obraz nie został dotąd przebadany pod kątem techniki malarskiej, rodzaju drewna, z którego wykonano podłoże, i konstrukcji. 


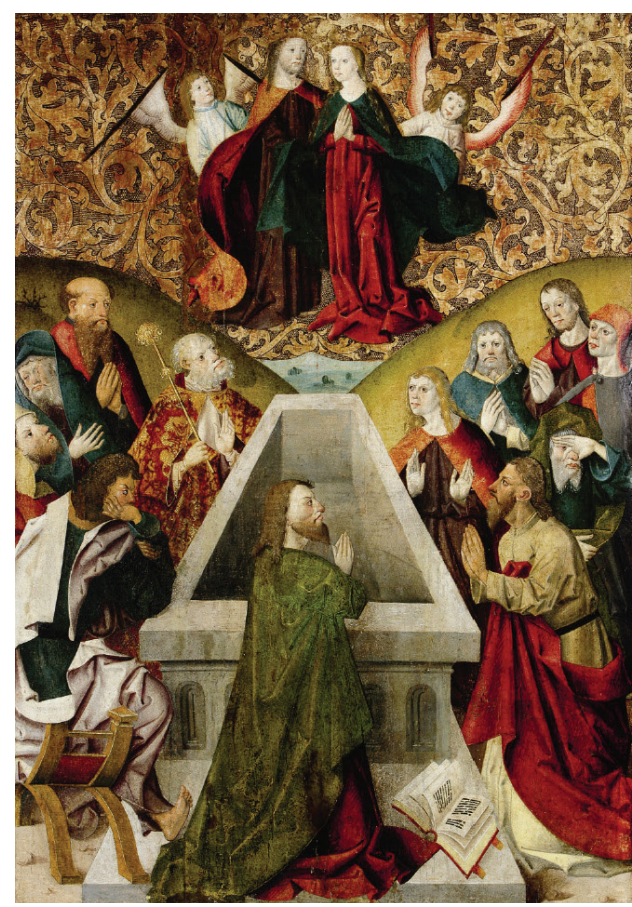

Il. 1. Warsztat wielkopolski, Wniebowzięcie Marii, początek XVI w., Muzeum Narodowe w Poznaniu, fot. ze zbiorów autora

starzec z lewej strony, z siwymi włosami, zarostem i łysiną czołową, trzymający $\mathrm{w}$ prawicy kropidło to $\mathrm{z}$ całą pewnością św. Piotr; młodzieniec bez zarostu o długich blond włosach jest być może św. Janem Ewangelistą. Obu wyróżniają szaty. Św. Piotr ubrany jest w purpurową kapę z wielkoraportowymi złotymi wzorami, a domniemany św. Jan Ewangelista - w purpurowy płaszcz z drobnym, gęstym wzorem wyszytym złotą nicią. Stroje pozostałych apostołów są skromniejsze i jednolite kolorystycznie: turkusowe, purpurowe, zielone, szare i fioletowe o różnych odcieniach. Niektórzy mają na głowach kaptury lub czepce. Ukazani są na tle dwóch symetrycznych względem siebie wzniesień, których zielone zbocza opadają łagodnie, chowając się za ścianą sarkofagu. Partia nad nimi wygląda jak zasłaniająca niebo złota, wzorzysta kotara, spod której (u dołu nad sarkofagiem) prześwituje między wzgórzami skrawek spowitego w błękit pejzażu. Możliwe, że symbolizuje on raj - cel podróży Marii. Całość przepojona jest nieskomplikowanym ładem.

Przytoczone motywy mają swoją podstawę literacką w Ewangeliach apokryficznych ${ }^{2}$. Niemal wszystkie informują, że gdy życie Marii dobiegało kresu, ponadnaturalne siły przywiodły do jej domu rozproszonych po świecie apostołów - datowany na lata 460-580 apokryf Transitus Jana Teologa podaje, że niektórzy z nich już wówczas nie żyli i specjalnie na tę okoliczność zostali wskrzeszeni ${ }^{3}$. Przybywszy na miejsce, modlili się przy konającej Marii, byli świadkami zabrania jej duszy do nieba przez Chrystusa, a potem wzięli udział w jej pogrzebie. Powstała pod koniec VI w. Historia Eutymiacka mówi o tajemniczym zniknięciu ciała Marii z grobu 4 . Datowany na V-VI w. Transitus Melitona z Sardes wspomina o zmartwychwstaniu Marii i zabraniu jej do nieba przez Chrystusa w asyście aniołów ${ }^{5}$, natomiast Transitus Józefa z Arymatei - o królewskości Marii („Wtedy Maryja

2 Ewangelie apokryficzne. Apokryfy Nowego Testamentu, red. Marek Starowieyski, Lublin 1986, s. 548-589. Podłoże literackie i ikonografię sceny Wniebowzięcia omawia Krystyna Secomska, Wniebowzięcie w kościele parafialnym w Warcie. Analiza ikonograficzna [w:] Malarstwo gotyckie w Wielkopolsce. Studia o dziełach i ludziach, red. Adam S. Labuda, Poznań 1994, s. 121 n.

3 Ewangelie apokryficzne..., s. 566-567.

4 Ibidem, s. 587.

Ibidem, s. 581-582. 
umyła się i odziała jak królowa, i wyglądała przybycia Syna swego, jak to był jej przyrzekł") $)^{6}$. Grecki apokryf z VI w. (?), Transitus $R$, mówi o apostołach czuwających przy grobie ${ }^{7}$. Apokryfy asumpcjonistyczne podkreślają doniosłą rolę św. Piotra, który pełnił funkcję celebransa w uroczystościach pogrzebowych Marii ${ }^{8}$. Podnoszą też znaczenie św. Jana Ewangelisty jako ukochanego ucznia Chrystusa, któremu ten powierzył swoje tajemnice i który zachował dziewiczą czystość ${ }^{9}$. Pochodzenie obrazu jest niejasne. W katalogu kolekcji Mielżyńskich, wydanym w 1881 r., napotykamy na najwcześniejszą wzmiankę o nim: „Oryginalny ten obraz przywiózł był z Włoch jeden z żyjących w pocz. XVI w. braci Opalińskich z Bnina, albo biskup, albo Piotr, i ofiarował do jednego z kościołów w dobrach Opalenickich, skąd dopiero w czasach naszych został usunięty jako bardzo zniszczony (Nabył konserwator H.F. za pieniądze ofiarowane przez hr. Józefa Mielżyńskiego z Iwna)"10. W niektórych późniejszych publikacjach podawano, że obraz może pochodzić z Opalenicy ${ }^{11}$ lub nawet wskazywano na konkretny kościół w tym mieście ${ }^{12}$. Są to jednak hipotezy niepotwierdzone innymi przekazami. A zatem należy podchodzić do nich ostrożnie, tym bardziej że informacja o przywiezieniu obrazu z Włoch, zważywszy na jego styl, brzmi nieprawdopodobnie.

Niejasna jest też pierwotna funkcja tego dzieła. Nie zachowała się oryginalna rama - obecną wykonano w $1998 \mathrm{r}$. Nie wiadomo zatem, czy był to obraz samodzielny, czy środkowa partia nastawy skrzydłowej.

Poza wspomnianą publikacją z 1881 r. oraz drugą z 1912 r., w której obraz jest określony jako dzieło szkoły frankońskiej z XV w. ${ }^{13}$, wszyscy piszący o nim

6 Ibidem, s. 581. Królewskość Marii najsilniej podkreślały pisma koptyjskie z VI w., które omawia Secomska, Wniebowzięcie w kościele parafialnym $w$ Warcie..., s. 129.

7 Ibidem, s. 563.

8 Ibidem, s. 557, 559, 561 (Transitus R), s. 571 (Transitus Jana Teologa), s. 577 (Transitus Melitona $z$ Sardes).

$9 \quad$ Ibidem, s. 555 n. (Transitus R), s. 577 (Transitus Melitona z Sardem).

10 Galerya obrazów malarzy polskich znajdująca się w Muzeum imienia Mielżyńskich pod zarządem Towarzystwa Przyjaciół Nauk w Poznaniu, Poznań 1881, s. 39, kat. 229.

11 Zofia Białłowicz-Krygierowa, Galeria sztuki średniowiecznej [w:] Muzeum Narodowe w Poznaniu. Przewodnik, Poznań 1977, s. 18, il. 14; Andrzej Woziński, Galeria sztuki średniowiecznej. Przewodnik, Poznań 1990, s. 14; Adam S. Labuda, Malarstwo tablicowe $w$ Wielkopolsce. Szkice do dziejów kształtowania się środowiska artystycznego na przełomie średniowiecza i czasów nowych [w:] Malarstwo gotyckie w Wielkopolsce..., s. 82, 115, 154, 183; idem, Malarstwo tablicowe w Wielkopolsce, na Kujawach i Mazowszu [w:] Malarstwo gotyckie $w$ Polsce, t. 1, Synteza, red. Adam S. Labuda, Krystyna Secomska, Warszawa 2004, s. 328, 331; Paweł Freus, Małopolski typ Wniebowzięcia Marii [w:] Visibilia et Invisibilia w sztuce średniowiecza. Księga poświęcona pamięci profesor Kingi Szczepkowskiej-Naliwajek, red. Artur Badach, Monika Janiszewska, Monika Tarkowska, Warszawa 2009, s. 245.

12 Leszek Wetesko sugerował, że obraz pochodzi z kościoła św. Marcina w Opalenicy, zob. Maior Polonia Sacra. Sztuka sakralna w średniowiecznej Wielkopolsce. Historia pewnych tematów [katalog wystawy], Muzeum Początków Państwa Polskiego w Gnieźnie, Gniezno 1997, s. 79 , kat. C. 27 , il. 59.

${ }_{13}$ Katalog Galeryi obrazów w Muzeum im. Mielżyńskich Towarzystwa Przyjaciół Nauk w Poznaniu, Poznań 1912, s. 37, kat. 232. 
Andrzej uważali, że jest on produktem wielkopolskim lub - precyzyjniej mówiąc - pozWoziński nańskim, z około 1500 r., początku lub drugiej dekady XVI w. bądź z około 1520 r. ${ }^{14}$ Najwnikliwiej pod względem warsztatowym spojrzał na dzieło Adam S. Labuda, przypisując je twórcy obrazu Marii z Dzieciątkiem znajdującego się w kościele parafialnym w Brdowie i wiążąc z Poznaniem ${ }^{15}$.

Kilkakrotnie zwracano uwagę na redakcję ikonograficzną obrazu i jej wymowę, zwłaszcza w odniesieniu do innych prac z terenu Wielkopolski ukazujących ten sam temat. Alicja Karłowska-Kamzowa uznała dzieło za uproszczoną replikę Wniebowzięcia Marii z kościoła bernardynów w Warcie (obecnie w katedrze we Włocławku), datowanego na około 1490 r. i przypisywanego niegdyś Franciszkowi z Sieradza, a teraz Janowi Wielkiemu ${ }^{16}$. Badaczka twierdziła, że umieszczony w centrum pusty sarkofag może wskazywać na „ponadludzkie uprawnienia Marii”. Sądziła, że w Wielkopolsce wytworzyła się lokalna tradycja ikonograficzna, albowiem we Wniebowzięciach Marii w środkowej kwaterze młodszego retabulum w kościele bernardynów w Warcie (tzw. Warta II) z początku XVI w. oraz w analogicznej partii zaginionego tryptyku z 1521 r. z kolegiaty w Szamotułach można doszukać się podobieństw kompozycyjnych ${ }^{17}$. Do tej grupy obrazów o zbliżonej ikonografii Zofia Białłowicz-Krygierowa dołączyła kwaterę retabulum w kościele parafialnym w Kobylinie, twierdząc, że jest ona najbliższa stylowo obrazowi z muzeum poznańskiego ${ }^{18}$. Zdaniem Labudy pusty grób i zabranie Marii w postaci cielesnej (wraz z duszą) do nieba przez Chrystusa-Oblubieńca świadczą o jej czystości i Niepokalanym

14 Michał Walicki, Polska sztuka gotycka [katalog wystawy], Instytut Propagandy Sztuki, Warszawa 1935, s. 51, kat. 183, tabl. C; Tadeusz Dobrowolski, Wystawa polskiej sztuki gotyckiej w Warszawie, „Rocznik Krakowski” 1935, t. 26, s. 16; Muzeum Wielkopolskie w Poznaniu. Zbiory sztuki, oprac. Nikodem Pajzderski, Poznań 1939, s. 14, kat. 23; Alicja Karłowska-Kamzowa, Malarstwo (Sztuka gotycka) [w:] Dzieje Wielkopolski, red. Jerzy Topolski, Poznań 1969, t. 1, s. 433; Aniela Sławska, Muzeum Narodowe w Poznaniu. Przewodnik, Poznań 1971, s. 14; Białłowicz-Krygierowa, Galeria sztuki średniowiecznej..., s. 18; Zbiory Poznańskiego Towarzystwa Przyjaciół Nauk w Muzeum Narodowym w Poznaniu [katalog wystawy], red. Magdalena Warkoczewska, Muzeum Narodowe w Poznaniu, Poznań 1982, s. 64, kat. 12; Woziński, Galeria sztuki średniowiecznej..., s. 14; Labuda, Malarstwo tablicowe w Wielkopolsce..., s. 82; Wetesko, Maior Polonia Sacra..., s. 79; Labuda, Malarstwo tablicowe w Wielkopolsce, na Kujawach..., s. 328, 331; Adam Soćko, Wniebowzięcie Najświętszej Marii Panny [w:] Ars una species mille. 150 dziet na 150-lecie Muzeum Narodowego w Poznaniu ze zbiorów Poznańskiego Towarzystwa Przyjaciót Nauk [katalog wystawy], red. Dorota Suchocka, Muzeum Narodowe w Poznaniu, Poznań 2007, kat. 18, s. 50-51; Freus, Małopolski typ Wniebowzięcia..., s. 245.

15 Labuda, Malarstwo tablicowe w Wielkopolsce..., s. 115, il. 47, 50; idem, Malarstwo tablicowe $w$ Wielkopolsce, na Kujawach..., s. 328, 331.

16 Jerzy Gadomski, Gotyckie malarstwo tablicowe Małopolski 1460-1500, Warszawa 1988, s. 149-150, il. 115; idem, Jan Wielki. Krakowski malarz z drugiej połowy wieku XV, Kraków 2005, s. 47-51; zob. też Jacek Dębicki, Obraz Wniebowzięcie Panny Marii z kościoła Ojców Bernardynów w Warcie - nieodczytane dotąd arcydzieło krakowskiej ikonografii [w:] Visibilia et Invisibilia..., s. 257-286.

17 Karłowska-Kamzowa, Malarstwo (Sztuka gotycka)..., s. 433.

18 Białłowicz-Krygierowa, Galeria sztuki średniowiecznej..., s. 18. 
Poczęciu. Zarówno Labuda ${ }^{19}$, jak i Krystyna Secomska ${ }^{20}$ brali pod uwagę możliwość istnienia lokalnej tradycji, którą oprócz wyżej wymienionych dzieł reprezentuje rzeźbione Wniebowzięcie Marii w kościele św. Wojciecha w Poznaniu. Adam Soćko powtórzył powyższe rozpoznania dotyczące ikonografii i treści analizowanego obrazu ${ }^{21}$. Ponadto Paweł Freus zwrócił niedawno uwagę na to, że gest Chrystusa, który ujmuje Marię pod ramię, korony na ich głowach, Oblubieńcy zwróceni ku sobie oraz aniołowie trzymający ich płaszcze mają analogie w małopolskich redakcjach tematu: w ukończonym w $1491 \mathrm{r}$. retabulum ołtarza głównego w kościele Wniebowzięcia Panny Marii w Książnicach Wielkich, w Ołtarzu Mariackim Wita Stosza, na miniaturze w Pontyfikale Erazma Ciołka (około 1510, Kraków, Fundacja XX. Czartoryskich, Biblioteka, Ms. Czart. 1212, fol. 22v) oraz w nastawie ołtarza głównego w kościele Bożego Ciała w Bieczu (około 1530-1540) ${ }^{22}$.

Z dotychczasowych badań wynikałoby, że poznański obraz jest dziełem dość standardowym pod względem formy i treści, tymczasem - jak pokażemy w dalszej części artykułu - zastosowano w nim rozwiązania i motywy odbiegające od ikonograficznej praktyki i częściowo niemające pokrycia w przekazach literackich.

Intrygująco przedstawia się sprawa tożsamości apostoła na pierwszym planie obrazu. Wyróżnia go kilka cech: znajduje się najbliżej widza, malarz umieścił go na osi kompozycji, na czymś w rodzaju proscenium, pozostali apostołowie są od niego nieco odsunięci. Przypomina Chrystusa modlącego się na Górze Oliwnej. Apokryfy asumpcjonistyczne wspominają o tym miejscu. W Transitusie $R$ św. Paweł zwraca się do św. Piotra tymi słowy: „Ojcze Piotrze, wiedz, że ja dopiero przyjąłem chrzest i posiadam zaledwie pierwociny wiary w Jezusa Chrystusa, i nie spotkałem jeszcze mistrza, który by opowiedział mi tajemnice chwalebne. Słyszałem jednak, że On objawił się wam wszystkim na Górze Oliwnej, błagam was więc, byście mnie o tym wszystkim pouczyli”23. Transitus Melitona $z$ Sardes podaje, że po śmierci Chrystusa Maria mieszkała w domu obok Góry Oliwnej, na Górze Oliwnej modliła się przed śmiercią, a u jej podnóża, w Dolinie Jozafata, została pochowana ${ }^{24}$. Taką samą lokalizację grobu Marii wskazuje Transitus Józefa $z$ Arymatei ${ }^{25}$, zaś Historia Eutymiacka, że spoczęła w samym Getsemani ${ }^{26}$. Czy poza apostoła upodobnionego do Chrystusa miała wywoływać skojarzenia z miejscem, w którym rozegrały się istotne wydarzenia w życiu obojga? Czy w ten sposób twórca chciał jeszcze silniej podkreślić związek Chrystusa-Oblubieńca i Marii-Oblubienicy? Brakuje analogicznych rozwiązań, w związku

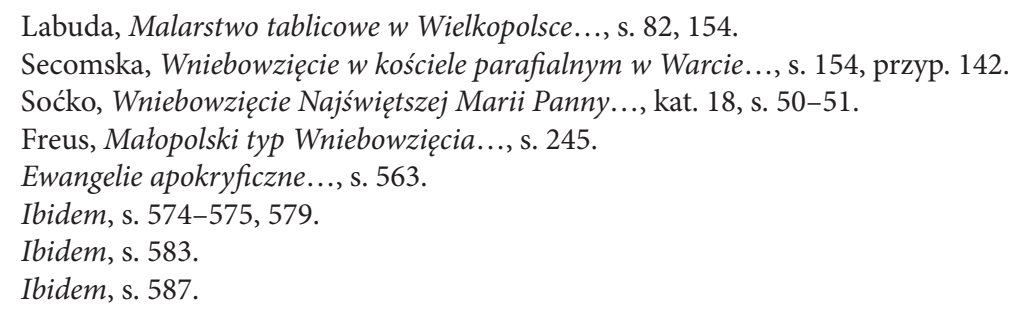


Andrzej z czym powyższe pytania pozostaną bez odpowiedzi. Należy wziąć również pod Woziński uwagę możliwość, że apostołem tym jest św. Tomasz, który według Transitusa Józefa z Arymatei jako pierwszy zauważył, że ciało Marii zniknęło z grobu. Musiał dwukrotnie przekonywać o tym pozostałych uczniów Chrystusa, gdyż ci sądzili, że nie uwierzył w pochowanie Marii we wskazanym przez nich miejscu: „Wtedy prawie już zagniewani przystąpili do grobu, który był na nowo wykuty w skale, podnieśli kamień, ale gdy nie znaleźli ciała, nie wiedzieli, co rzec, bo przekonały ich słowa Tomasza" ${ }^{27}$. Za taką identyfikacją przemawiałoby umieszczenie tego apostoła jako jedynego przed przednią ścianką pustego sarkofagu. Być może w ten sposób twórca dzieła chciał silniej podkreślić, że Maria przed Wniebowzięciem zmartwychwstała.

Wyjaśnienia wymaga znaczenie otwartej księgi leżącej obok tego apostoła. W Transitusie $R$ Maria przed śmiercią mówi do św. Jana: „[...] weź tę oto książkę, w której znajdowała się tajemnica, ponieważ Nauczyciel, gdy miał pięć lat, oznajmił mi wszystko o stworzeniu, a was dwunastu zapisał w niej także"28. Transitus Józefa z Arymatei przekazuje, że Maria została wzięta do nieba „wśród psalmów, hymnów i śpiewu Pieśni nad Pieśniami” ${ }^{29}$. Na wcześniejszym obrazie Wniebowzięcie z kościoła w Warcie na sarkofagu Marii ukazano proroków ${ }^{30}$. Wydaje się zatem, że księga może symbolizować wypełnienie przepowiedni.

$\mathrm{Na}$ obrazie z muzeum poznańskiego zaskakuje - w porównaniu z innymi dziełami - zachowanie apostołów. Jerzy Gadomski o starszym obrazie z Warty pisał: „Zbici w ciasne gromady apostołowie stanowią wyjątkowo trafne studium zbiorowego, psychicznego napięcia; w różny sposób objawiają zdumienie wobec nadprzyrodzonego zjawiska [...]"31. Na analizowanej tablicy reakcje apostołów nie są tak wyraziste i jednoznaczne. Widniejący w głębi po prawej stronie, za domniemanym św. Janem Ewangelistą, apostoł z siwymi włosami i zarostem, ubrany w jasny turkusowy płaszcz, w niewielkim stopniu uczestniczy w wydarzeniu: złożył ręce do modlitwy jak (niemal) wszyscy, lecz przede wszystkim szuka kontaktu z widzem, patrzy wprost na niego. Podobne rozwiązania nie należały do wyjątkowych w okresie powstania obrazu z Poznania. Kilku apostołów spogląda w górę, lecz ich wzrok zdaje się omijać unoszących się nad sarkofagiem Marię i Chrystusa. Apostołowie - pierwszy od lewej, siedzący na tzw. krześle Dantego, oraz najdalszy z prawej strony - być może patrzą na sarkofag, lecz na ich obliczach trudno doszukać się wstrząsu wywołanego cudem. Spojrzenia innych nie mają adresatów, skierowane są poza scenę. Apostoł przy lewej krawędzi obrazu, z głową osłoniętą turkusowym kapturem, odwraca się od sarkofagu. Podobnie czyni apostoł w zielonym kapturze z prawej strony, jednocześnie wycierając nos. Całość jest słabo powiązana pod względem dramatycznym,

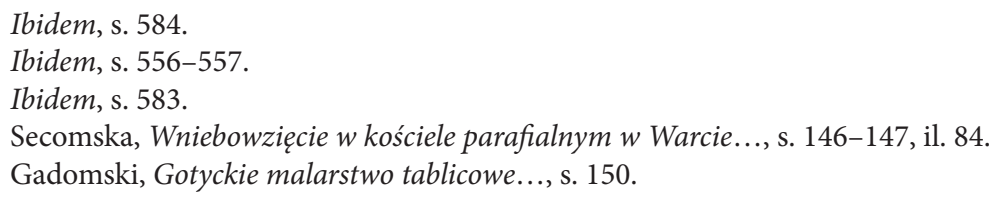


co można tłumaczyć m.in. niedostatkiem umiejętności malarza.

Osobliwością wyobrażonej sceny jest obecność krzesła przy sarkofagu - siedzi na nim w dziwnie skomplikowanej pozie nierozpoznany apostoł. Mebel ten nie występuje w ikonografii Wniebowzięcia Marii; nie wspominają o nim źródła literackie. Uwagę zwraca również jego niezwykłe ustawienie. Mimo że jedna noga stoi na cokole sarkofagu, a druga niżej, na ziemi, krzesło zachowuje równowagę.

Skąd wzięło się na analizowanym obrazie zachowanie apostołów nie w pełni przystające do sytuacji? Odpowiedź znajdujemy na sztychu niderlandzkiego Mistrza IAM z Zwolle przedstawiającym Ostatnią Wieczerzę (L. 2, il. 2) $)^{32}$. Krzesło wraz z siedzącym na nim apostołem, grupa po lewej stronie, oprócz św. Piotra, oraz trzech uczniów Chrystusa najbliżej prawej

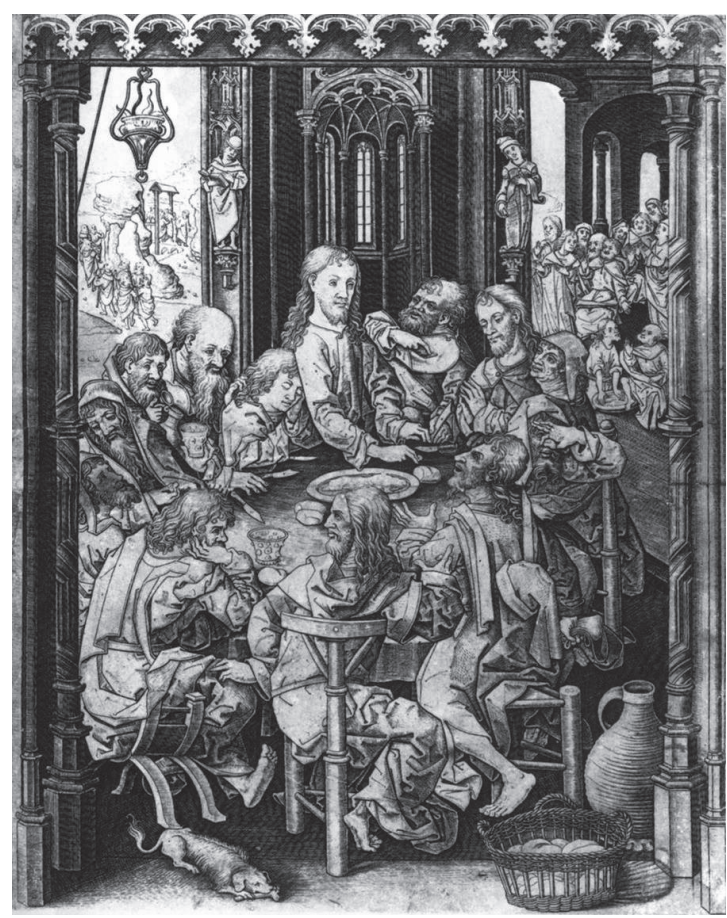

Il. 2. Mistrz IAM z Zwolle, Ostatnia Wieczerza, około 1485-1490, fot. ze zbiorów autora krawędzi obrazu - to cytaty z tego miedziorytu. Wydaje się, że inne postacie i motywy mogą być również swobodnymi parafrazami wzorców graficznych. Klęczący apostoł na pierwszym planie wygląda jak uproszczona replika Chrystusa ze sceny W Ogrójcu Martina Schongauera (L. 19) ${ }^{33}$ lub króla Melchiora z Pokłonu Trzech Króli tego samego twórcy (L. 6) ${ }^{34}$. Forma szat Marii i Chrystusa zdaje się nawiązywać do stylistyki drzeworytów Michaela Wohlgemuta i Wilhelma Pleydenwurffa, zamieszczonych w wydanym w 1491 r. przez słynną norymberską oficynę Antona Kobergera popularnym utworze dewocyjnym Stephana Fridolina Schatzbehalter oder Schrein der wahren Reichtümer... ${ }^{35}$. Rozwiany, falujący płaszcz Chrystusa, którego brzegi zaginają się, tworząc formy przypominające małżowinę, przywodzi na myśl analogiczną część odzienia Zbawiciela

32 Max Lehrs, Geschichte und kritischer Katalog des deutschen, niederländischen und französischen Kupferstichs im XV. Jahrhundert, Bd. 7, Wien 1930, s. 180; Friedrich Wilhelm Heinrich Hollstein, Dutch and Flemish Etchings, Engravings and Woodcuts ca. 1450-1700, vol. 12, Masters and Monogrammists of the 15th century, Amsterdam 1955, s. 254; Ursula Mayr-Harting, Early Netherlandish Engraving c. 1440-1540, Ashmolean Museum, Oxford 1997, s. 22-23, kat. 31.

33 Lehrs, Geschichte und kritischer Katalog..., Bd. 5, Wien 1925, s. 122.

34 Ibidem, s. 56, il. 132, nr 362.

35 Stephan Fridolin, Der Schatzbehalter. Ein Andachts- und Erbauungsbuch aus dem Jahre 1491 mit 91 Holzschnitten und 2 Textseiten in Faksimile, Wiesbaden 1962. 
Andrzej w Zstąpieniu do Otchłani, szatę anioła asystującego Bogu Ojcu i Chrystusowi Woziński na karcie z 24 Starcami Apokaliptycznymi (na pierwszym planie z lewej strony) oraz płaszcz Abrahama w scenie Ofiary Izaaka ${ }^{36}$. Udrapowanie sukni Marii z rozkloszowaną fałdą pod wysuniętym lewym kolanem, krótką ukośną fałdą nad nim, długimi równoległymi fałdami wzdłuż prawej nogi oraz gąszczem kątowo załamujących się drobnych fałd u stóp ma odpowiedniki w formie sukni córki Jeftego, witającej go po zwycięstwie nad Amonitami (Sdz. 11,32-34) oraz szaty Chrystusa w scenie ze śmiercią ${ }^{37}$.

Fakt, że twórca obrazu sięgnął po sztych z Ostatnią Wieczerzą, aby stworzyć osnowę znacznej części kompozycji Wniebowzięcia Marii, do pewnego stopnia zaskakuje, niemniej jednak jego decyzja (choć być może ktoś podsunął mu takie rozwiązanie) nie była pozbawiona racjonalnych podstaw. Oba wydarzenia pod pewnymi względami są podobne. Łączy je spotkanie dwunastu apostołów w jednym miejscu, w doniosłej chwili, a także silna reakcja emocjonalna zebranych na to, co się stało bądź ma się stać - na ich twarzach maluje się zdumienie, niedowierzanie, groza. W konsekwencji w ikonografii obu tematów występują identyczne lub porównywalne motywy. W kompozycjach doszukać się można zbliżonych schematów, pokrewna jest też aura. Być może walory artystyczne niderlandzkiego sztychu, wyrazistość postaci zasiadających wokół stołu w wieczerniku, intensywność uczuć, z którą świetnie współgra gęsta forma, nerwowy dukt kreski i silny światłocień miały wpływ na to, że na wielkopolskim obrazie pojawiły się zapożyczenia z tego dzieła. Malarz dość wiernie cytował wybrane elementy, nie starając się zbytnio dostosować ich do odmiennego tematu - stąd wspomniane wyżej niekonsekwencje i brak spójności.

Zjawisko posługiwania się przez twórców różnych specjalności podkładami graficznymi było w drugiej połowie XV i na początku XVI w. wszechobecne ${ }^{38}$.

36 Getty Research Institute, sygn. INCUN 84B, il. 79, 71, 18, https://archive.org/details/gri_ 33125008960557/page/n13/mode/2up [dostęp: 13.04.2020].

37 Ibidem, il. 19, 45.

38 Ma ono obfitą literaturę, w związku z czym ograniczam się do podania wybranych pozycji: Edith Hessig, Die Kunst des Meisters E.S. und die Plastik der Spätgotik, Berlin 1935; Johann Michael Fritz, Gestochene Bilder. Gravierungen auf deutschen Goldschmiedearbeiten der Spätgotik, Köln 1966; Albrecht Dürer. His Prints and his Influence [katalog wystawy], P. \& D. Colnaghi \& Co.'s Galleries, London, London 1971; Anne H. van Buren, Sheila Edmunds, Playing Cards and Manuscripts. Some Widely Disseminated Fifteenth Century Model Sheets, „The Art Bulletin” 1974, nr 1, s. 12-30; James Marrow, A Book of Hours from the Circle of the Master of the Berlin Passion. Notes on the Relationship Between Fifteenth-Century Manuscript Illumination and Printmaking in the Rhenish Lowland, „The Art Bulletin” 1978, nr 4, s. 590-616; Ernst Ullmann, Albrecht Dürer und die Wirkung der Graphik [w:] Le stampe e la diffusione delle immagini e degli stili, a cura Henri Zerner, Bologna 1978, s. 7-16 (Atti del XXIV Congresso Internazionale di Storia dell'Arte, 8); Lesley Baier, The spread of Dürer's woodcut style. A Didactic Exhibition [katalog wystawy], Yale University Art Gallery, New Haven, New Haven 1981; Dürers Verwandlung in der Skulptur zwischen Renaissance und Barock [katalog wystawy], Hg. Herbert Beck, Bernhard Decker, Liebieghaus Museum alter Plastik, Frankfurt am Main, Frankfurt am Main 1981; Martha Wolff, Some Manuscript Sources for the Playing-Card Master's Number Cards, „The Art Bulletin” 1982, nr 4, s. 587-600; eadem, 
Korzystali z nich niemal wszyscy, niezależnie od kwalifikacji zawodowych i talentu, wśród nich najwięksi, jak Tilman Riemenschneider ${ }^{39}$ czy - po drugiej stronie Alp - Andrea Mantegna ${ }^{40}$. Poznański zabytek jest więc jednym z niezliczonych przykładów tej praktyki, lecz jednocześnie należy do mniej licznych dzieł, które pokazują, że niekiedy przybierała ona nieco bardziej skomplikowany przebieg - polegała bowiem na kompilacji motywów zaczerpniętych z różnych źródeł i ich ikonograficznym przekształceniu ${ }^{41}$. Oto dwa inne przypadki, w których zastosowano tę poszukującą metodę. Malarzem, który wielokrotnie wykorzystywał grafiki, był działający w Ulm Jörg Stoker (około 1461 - po 1527) ${ }^{42}$. Drzeworyty,

Observations on the Master of the Playing Cards and Upper Rhenish Painting [w:] Essays in Northern European Art Presented to Egbert Haverkamp-Begemann on his Sixtieth Birthday, Doornspijk 1983, s. 299-302; Matthias Mende, Dürer-Medaillen. Münzen, Medaillen, Plaketten von Dürer, auf Dürer, nach Dürer, Nürnberg 1983; Dürers Apokalypse und ihre Wirkung [katalog wystawy], Herzog Anton Ulrich-Museum, Kupferstichkabinett, Braunschweig 1994; Johann Michael Fritz, Martin Schongauer und die Goldschmiede [w:] Le beau Martin. Etudes et mises au point. Actes du colloque organisé par le musée d'Unterlinden à Colmar les 30 septembre, 1er et 2 octobre 1991, Colmar 1994, s. 175-184; Giulia Bartum, Albrecht Dürer and his Legacy. The Graphic Work of a Renaissance Artist [katalog wystawy], British Museum, London, London 2002; Barbara Butts, Albrecht Dürer and the Modernization of Stained Glass, „Master Drawings” 2003, vol. 41, s. 341-358; Stephan Kemperdick, Martin Schongauer. Eine Monographie, Fulda 2004, s. 36 n., s. 247-270 (Studien zur internationalen Architektur- und Kunstgeschichte, 32); La grande fortuna. Riflessi, copie e traduzioni da Dürer nelle incisioni della Pinacoteca Tosio Martinengo [katalog wystawy], a cura Roberta D’Adda, Tosio Martinengo, Pinacoteca, Brescia, Brescia 2007; Janez Höfler, Der Meister E. S. Ein Kapitel europäischer Kunst des 15. Jahrhunderts, Regensburg 2007 (rozdz. Der Meister E. S. und die Skulptur oraz Zur Rezeption des Meisters E. S. in der europäischen Kunst des 15. Jahrhunderts, s. 121-159); Joanna Sikorska, Miedzioryt XV wieku i jego odrębność w sztuce późnego średniowiecza. Problemy badawcze, „Biuletyn Historii Sztuki” 2008, nr 1-2, s. 118-119 (tutaj wybór literatury); Jeffrey Chipps Smith, Dürer and Sculpture [w:] The Essential Dürer, ed. Larry Silver, Jeffrey Chipps Smith, Philadelphia 2010, s. 74-98; Christoph Metzger, When Pictures began to Travel. The Role of Prints in the Transmission of Images [w:] Van Eyck to Dürer. The Influence of Early Netherlandish Painting on European Art 1430-1530 [katalog wystawy], ed. Till-Holger Borchert, Groeningenmuseum Bruges, London 2011, s. 105-111.

39 Ewald M. Vetter, Alfred Walz, Die Rolle des Monogrammisten AG im Werk Riemenschneiders, „Anzeiger des Germanischen Nationalmuseums” 1980, s. 48-73; Hartmut Krohm, Schongauersche Bildgedanke des „Noli me tangere” aus Münnerstadt - Druckgraphik und Bildgestalt des nichtpolychromierten Flügelaltars [w:] Flügelaltäre des späten Mittelalters, Staatliche Museen zu Berlin Preußischer Kulturbesitz, Skulpturensammlung, Hg. Hartmut Krohm, Eike Oellermann, Berlin 1992, s. 84-102; Jan Nicolaisen, Die Verwendung der Kupferstiche Martin Schongauers in der Schnitzwerkstatt Tilman Riemenschneiders [w:] Le beau Martin..., s. 251-284; Fritz Koreny, Riemenschneider and the Graphic Arts [w:] Tilman Riemenschneider, c. 1460-1531, ed. Julien Chapuis, New Haven, Conn.-London 2004 (Studies in the History of Art, 65), s. 108-110.

40 Andrea Mantegna [katalog wystawy], ed. Jane Martineau, Metropolitan Museum of Art, New York, Royal Academy of Arts, London, London 1992, s. 44-45; Francis Ames-Lewis, A Northern Source for Mantegna's Adoration of Shepherds, „Print Quarterly” 1992, nr 3, s. 268-271.

${ }_{41}$ Fenomen przekształcenia ikonograficznego szerzej prezentuje Jan Białostocki, Tradycje i przekształcenia ikonograficzne [w:] idem, Teoria i twórczość. O tradycji i inwencji w teorii sztuki i ikonografii, Poznań 1961, s. 137-159.

${ }^{42}$ Daniela Gräfin von Pfeil, Jörg Stocker - ein verkannter Maler aus Ulm [w:] Meisterwerke massenhaft. Die Bildhauerwerkstatt des Niklaus Weckmann und die Malerei in Ulm um 1500 
Andrzej miedzioryty i rysunki służyły mu nie tylko jako pomoc w konstruowaniu komWoziński pozycji, lecz stanowiły także rodzaj wzornika, którego używał podczas negocjacji ze zleceniodawcami ${ }^{43}$. Wykorzystywał grafiki w trojaki sposób: cytując pojedyncze motywy, powtarzając całe sceny lub „składając” kompozycję z elementów zaczerpniętych $\mathrm{z}$ różnych rycin ${ }^{44}$. Tę ostatnią metodę zastosował na obrazie będącym wraz z Niesieniem Krzyża pozostałością retabulum pasyjnego z około $1500 \mathrm{r}$. (Ulm, Ulmer Museum) ${ }^{45}$. Kwatera ukazuje kilka scen w konwencji symultanicznej: Chrystusa budzacego św. Piotra pośród śpiących św. Jana Ewangelisty i św. Jakuba Starszego, Chrystusa modlacego się przed skała i nadlatującego anioła, czterech apostołów w głębi po prawej stronie oraz nadciągające wojsko prowadzone przez Judasza na dalszym planie. W tle widnieje wspaniały skalisty pejzaż z warownym miastem, kościołem i zamkiem na szczycie góry. Scena wymieniona jako pierwsza ma swój pierwowzór w prezentującym ten sam temat sztychu Mistrza IAM z Zwolle. W grafice ponad grupą postaci na pierwszym planie jej twórca umieścił w głębi Chrystusa modlącego się przed skałą. Stocker w swoim obrazie zmienił lokalizację tej sceny, umieszczając ją u czoła kompozycji, blisko prawej krawędzi obrazu. Nie cytował jednak w tym wypadku Niderlandczyka, lecz odpowiedni motyw ze wspominanego w innym miejscu miedziorytu Schongauera (L. 19). Na osi kompozycji, w miejscu, w którym na niderlandzkim sztychu znajdował się pogrążony w modlitwie Chrystus, malarz ukazał masyw skalny, porośnięty na szczycie zielenią i drzewami. Tło z wyobrażeniem miasta i zamku ma analogiczną formę do odpowiadającej mu partii miedziorytu Albrechta Dürera ukazującego zupełnie inny temat, a mianowicie Potwora morskiego ${ }^{46}$. Wypada też zauważyć, że Norymberczyk umieścił na sztychu, w głębi, na niewielkim cyplu nad wodą, biegnącego mężczyznę z wyrzuconymi w górę rękoma. Na obrazie w tym samym miejscu widzimy żołnierza wchodzącego na kładkę lub przewrócone drzwi, w równie ekspresyjnej, choć nie identycznej pozie.

Z grafik korzystał wybitny malarz antwerpski Joos van Cleve ${ }^{47}$. Niektóre motywy w swoich wczesnych pracach zapożyczał od niderlandzkiego miedziorytnika, Mistrza FVB ${ }^{48}$, w późniejszej twórczości wykorzystywał gra-

[katalog wystawy], Hg. Gerhard Weiland, Württembergischen Landesmuseum Stuttgart, Stuttgart 1993, s. 199-210; Manuel Teget-Welz, Bartholomäus Zeitblom, Jörg Stocker und die Ulmer Kunstproduktion um 1500 [w:] Jerusalem in Ulm. Der Flügelaltar aus St. Michael zu den Wengen [katalog wystawy], Hg. Eva Leistenschneider, Ulmer Museum, Ulm 2015, s. 10-25.

43 von Pfeil, Jörg Stocker..., s. 206.

44 Ibidem, s. 206.

45 Ibidem, s. 206-207, il. 282.

46 Ibidem, s. 206-207, il. 282-285.

47 Podaję jedynie najnowsze monografie dotyczące artysty; w nich czytelnik znajdzie pełną bibliografię: John Oliver Hand, Joos van Cleve. The Complete Paintings, New Haven-London 2004; Joos van Cleve. Leonardo des Nordens, Hg. Peter van den Brink, Stuttgart 2011; Micha Leeflang, Joos van Cleve. A Sixteenth-century Antwerp Artist and His Workshop, Turnhout 2015 (Me Fecit, 8).

48 Micha Leeflang, The Saint Reinhold Altarpiece by Joos van Cleve and his Workshop: New Insights into the influence of Albrecht Durer on the Working Process [w:] Making \& Marketing: 
fiki niezwykle cenionego (również w Niderlandach) Dürera. W 1516 r. sfinalizowano zamówienie gdańskiego bractwa św. Reinholda. Zamówiono retabulum, które zostało umieszczone na ołtarzu kaplicy brackiej w kościele Mariackim w Gdańsku (obecnie Muzeum Narodowe w Warszawie). Wykonano je w Antwerpii: partie rzeźbione w znanym warsztacie Jana de Moldera, zaś malarskie - w pracowni van Cleve ${ }^{49}$. Wzorami dla większości malowanych kwater były ryciny z Dużej i Małej Pasji. Micha Leeflang analizując podrysowania gdańskich scen, doszła do wniosku, że brak większych zmian w stosunku do graficznych pierwowzorów przemawia za tym, iż w warsztacie Klewejczyka najpierw wykonano według grafik powiększone rysunki na papierze, a następnie przeniesione je na podobrazie ${ }^{50}$. Artysta nie zawsze w całości kopiował ryciny. Kompozycja Modlitwy Chrystusa w Ogrójcu w znacznej mierze powtarza rozwiązanie z analogicznej sceny w Dużej Pasji. Van Cleve zmienił szczegóły: odwrócił Chrystusa oraz anioła podającego mu kielich, a grupę nadchodzących żołnierzy umieścił po przeciwnej stronie niż na rycinie ${ }^{51}$. Ponadto wprowadził do sceny formę zaczerpniętą z innej grafiki Dürera - drzeworytu ukazującego Wizję Chrystusa i siedmiu świeczników z cyklu Apocalipsis cum figuris z 1498 r. To stamtąd zaczerpnął klęczącą postać św. Jana Ewangelisty, którego w nowym kontekście uczynił modlącym się Chrystusem ${ }^{52}$. Podobne do wyżej opisanych praktyki z użyciem grafik nie należały u schyłku średniowiecza do wyjątków. W końcowej części artykułu omówimy jeszcze jeden zbliżony przypadek.

Warto poświęcić nieco uwagi samemu wzorcowi graficznemu, który w tak poważnym stopniu określił formę i ikonografię obrazu z Muzeum Narodowego w Poznaniu. Niewiele wiadomo o twórcy miedziorytu. Niewykluczone, że pod inicjałami IAM krył się działający w latach 1462-1504 w Zwolle malarz Jan van den Mynnesten ${ }^{53}$. Wykształcenie zawodowe mógł zdobyć w południowych

Studies of the Painting Process in Fifteenth- and Sixteenth-Century Netherlandish Workshops, ed. Molly Faries, Turnhout 2006, s. 26.

49 Jan Białostocki, Gdańskie dzieło Joosa van Cleve. Z dziejów artystycznych stosunków Gdańska z Niderlandami [w:] Studia Pomorskie, t. 1, red. Michał Walicki, Wrocław-Kraków 1957, s. 170-226; Ryszard Szmydki, Retables anversois en Pologne. Contribution à l'étude des rapports artistiques entre les anciens Pays-Bas Méridionaux et la région de Gdańsk au début du XVIe siècle, Brussel 1986, s. 23-73; Leeflang, Joos van Cleve..., s. 47-54, 112-117; zob. też Albert Boesten-Stengel, Joos von Cleves Reinhold-Altar. Masaccios Schatten erreichen via Antwerpen Danzig [w:] Die Danziger Marienkirche. Der Bau und ihre Ausstattung im europäischen Kontext, red. Tomasz Torbus, Gerhard Weilandt [w przygotowaniu].

50 Leeflang, The Saint Reinhold Altarpiece..., s. 25.

51 Ibidem, s. 18-19, il. 3-4.

52 Ibidem, s. 19, il. 5.

53 Lehrs, Geschichte und kritischer Katalog..., Bd. 7, s. 165-211; Hollstein, Dutch and Flemish Etchings..., vol. 12, Masters and Monogrammists..., s. 252-279; Berend Dubbe, Is Johan van den Mynnesten de Meester van Zwolle?, „Bulletin van het Rijksmuseum” 1970, vol. 18, s. 55-65; Jan Piet Filedt Kok, Master IAM of Zwoll the personality of a designer and engraver [w:] Festschrift to Erik Fischer. European drawings from six centuries, ed. Villads Villadsen, Copenhagen 1990, 


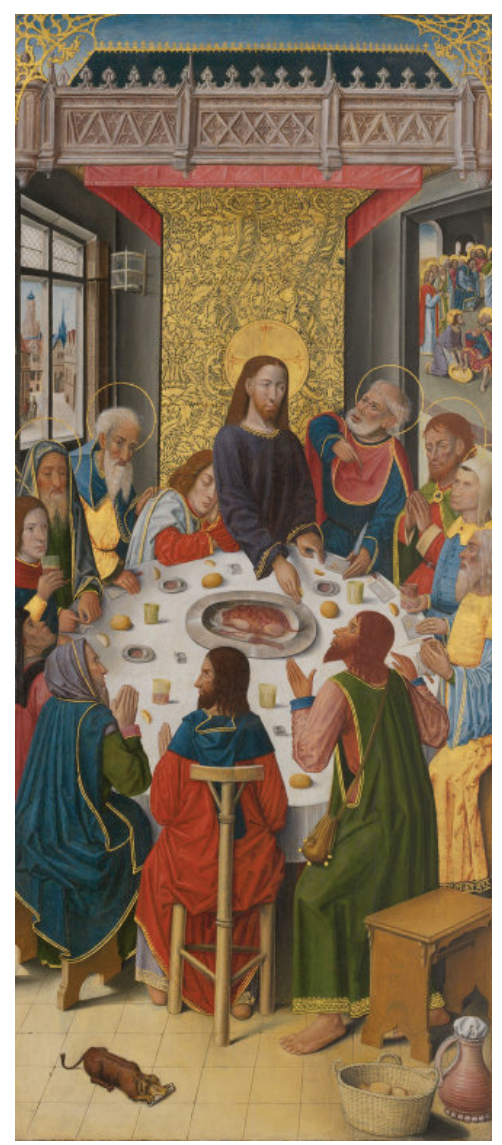

Il. 3. Ostatnia Wieczerza, kwatera $\mathrm{z}$ retabulum kartuzji Saint-Honoré w Thuison-les-Abbeville, około 1490-1500, The Art Institute w Chicago, fot. ze zbiorów autora i zachodnich Niderlandach. Badacze widzą w jego pracach powinowactwa stylistyczne $\mathrm{z}$ obrazami Rogiera van der Weyden, Geertegena tot Sint Jansa i Mistrza W z Kluczem, określanego też jako Mistrz WA. Niektóre sztychy twórcy IAM z Zwolle wyróżniają się ponadprzeciętną wielkością - w przybliżeniu $35 \times 25 \mathrm{~cm}$ - co każe przypuszczać, że funkcjonowały one jako substytuty znacznie droższych obrazów. Do takich należy właśnie Ostatnia Wieczerza o wymiarach $34,5 \times 26,8 \mathrm{~cm}$, datowana na lata około 1485-1490 $0^{54}$. Max Lehrs zaliczył ją wraz z dwoma innymi - Modlitwa w Ogrójcu i Pojmaniem Chrystusa (L. 3-4), do wczesnych prac artysty, twierdząc, że mogły stanowić one projekty dla reliefów, które miały być stacjami Drogi Krzyżowej ${ }^{55}$. Podobną opinię wyraziła Ursula Mayr-Harting, uznając, że osadzenie sceny w głębi wnętrza ujętego imitacjami architektonicznych elementów tworzących kadr może sugerować, że grafika służyła jako podkład dla płaskorzeźby $z$ drewna lub alabastru ${ }^{56}$. Rzeźbiarskich replik tego sztychu nie udało się - jak dotąd - odnaleźć, natomiast znamy je z innych mediów. Lehrs jako pierwszy podał kilka przykładów recepcji sztychu. Analogie do niego, aczkolwiek $\mathrm{z}$ wieloma zmianami, znalazł w malowanej kwaterze północnofrancuskiej nastawy ołtarzowej z lat około 1490-1500 z kartuzji Saint-Honoré w Thuison-les-Abbeville (Chicago, The Art Institute, il. 3) ${ }^{57}$. Zdaniem Godefridusa Joannesa Hoogewerffa obie kompozycje mogły powstać według

s. 341-356; Ilja Veldman, Images for the Eye and Soul: Function and Meaning in Netherlandish Prints (1450-1650), Leiden 2006, s. 21-22; Christian von Heusinger, Meister IAM von Zwolle [w:] De Gruyter Allgemeines Künstler-Lexikon. Die Bildenden Künstler aller Zeiten und Völker, Hg. Andreas Beyer, Bénédice Savoy, Wolfgang Tegethoff, Bd. 88, Matijin-Meixner, Berlin-Boston 2016, s. 409-410.

54 Podaję według egzemplarza w Ashmolean Museum w Oxfordzie, zob. Mayr-Harting, Early Netherlandish Engravings..., s. 22-23, kat. 31. Nieco inne wymiary - $347 \times 268 \mathrm{~mm}$ - podał Max Lehrs. Uczony odnotował istnienie ośmiu egzemplarzy tego sztychu oraz dwóch pomniejszonych trawestacji graficznych, zawierających zmiany w stosunku do pierwowzoru, zob. Lehrs, Geschichte und kritischer Katalog..., Bd. 7, s. 180, 182, 2a-2b.

55 Ibidem, s. 181.

56 Mayr-Harting, Early Netherlandish Engravings..., s. 22.

57 Lehrs, Geschichte und kritischer Katalog..., Bd. 7, s. 181. 
tego samego wzorca ${ }^{58}$. Należy podkreślić, że - mimo wielu różnic - w obu dziełach na pierwszym planie widnieją identycznie rozmieszczone: śpiący pies, kosz z chlebami i dzban, za prawym oknem w głębi rozgrywa się scena mycia nóg apostołom, co wskazuje na obopólne relacje, choć nie wiadomo, czy bezpośrednie. Lehrs zauważył, że sztych Mistrza IAM z Zwolle został powtórzony na srebrnym ołtarzyku domowym, powstałym w Salzburgu w 1494 r. (Nowy Jork, The Metropolitan Museum of Art - The Cloisters, il. 4) ${ }^{59}$. Jego otwartą wersję wypełniają reliefy $\mathrm{z}$ macicy perłowej, natomiast rewersy skrzydeł oraz odwrocie korpusu ozdobione są rytami w technice niello na srebrnych blachach. Wszystkie kwatery ukazują sceny pasyjne. Ta na odwrocie korpusu przedstawia Ostatnią Wieczerzę według Mistrza IAM z Zwolle. Jedyne poważniejsze zmiany w stosunku do pierwowzoru to brak psa i kosza na pierwszym planie oraz umieszczenie sceny we wnętrzu krytym sklepieniem krzyżowo-żebrowym.

Pod koniec średniowiecza sztuka północna była nie tylko bardzo dobrze znana w krajach śródziemnomorskich, lecz także bardzo ceniona ${ }^{60}$. Na południe Europy docierały m.in. grafiki Schongauera, Dürera i Mistrza IAM z Zwolle ${ }^{61}$, wśród nich Ostatnia Wieczerza. Lehrs odkrył, że miedziorytem tym posłużył się północnowłoski malarz, Gianfranceso da Tolmezzo, w cyklu pasyjnym z 1496 r.

58 Godefridus Joannes Hoogewerff, Noord-Nederlandsche schilderkunst, vol. 2, The Hague 1937, s. 32-43, il. 11.

59 Ibidem, s. 181; zob. też Filedt Kok, Master IAM of Zwoll..., s. 351, il. 10. Więcej o samym ołtarzyku zob. Ralf Schürer, Hausaltärchen [w:] Spiegel der Seligkeit: Privates Bild und Frömmigkeit im Spätmittelalter [katalog wystawy], Hg. Georg Ulrich Großmann, Germanisches Nationalmuseum, Nürnberg 2000, s. 254-255, kat. 80; Peter Barnet, Nancy Y. Wu, The Cloisters: Medieval Art and Architecture, New York-New Haven 2005, nr 108, s. 146-148, 198.

60 Zob. m.in. Till-Holger Borchert, Andreas Beyer, Le siècle de Van Eyck 1430-1530. Le monde méditerranéen et les primitfs flamands, Amsterdam 2002.

61 María Pilar Silva Maroto, Influencia de los grabados nórdicos en la pintura hispano-flamenca, „Archivo Español de Arte” 1988, nr 243, s. 271-289; Francis Ames-Lewis, On Domenico Ghirlandaio's Responsiveness to North European Art, „Gazette des Beaux-Arts” 1989, vol. 114, s. 111-122; Joseph Manca, Martin Schongauer et l'Italie [w:] Le beau Martin. Etudes et mises au point..., s. 223-228; Paolo Casadio, Incisione e pittura nella seconda metà del Quattrocento nel Friuli occidentale: l'uso delle stampe come modelli [w:] Il Quattrocento nel Friuli occidentale. Atti del convegno organizzato dalla Provincia di Pordenone nel mese di dicembre 1993, vol. 1, Pordenone 1996, s. 195-234; Fritz Koreny, Venice and Dürer [w:] Renaissance Venice and the North. Crosscurrents in the Time of Bellini, Dürer and Titian, ed. Bernard Aikema, Beverly Louise Brown, Venice 1999, s. 240, 247; Il Volto di Cristo [katalog wystawy], a cura Giovanni Morello, Gerhard Wolf, Palazzo delle Esposizioni, Roma, Milano 2000, s. 110-111, kat. IV.42; Kemperdick, Martin Schongauer..., s. 251, 265, 267; Veldman, Images for the Eye and Soul..., s. 31; Dorothee Heim, Tardogótico "internacional" o hispano-flamenco: las corrientes artísticas del Alto Rhin en el foco toledano [w:] El arte foráneo en España: presencia e influencia, ed. Miguel Cabañas Bravo, Madrid 2005, s. 37-50; Andrea Bubenik, Reframing Albrecht Dürer. The Appropriation of Art, 1527-1700, Farnham-Burlington 2013, s. 44-45; Enrico Pusceddu, Un Re di fiori per Nerone: modelli desunti dalle stampe nelle botteghe sardo-catalane (1488-1518), „Locvs Amœnvs” 2016, nr 14, s. 19-47; María del Carmen Lacarra Ducay, Influencia de Martín Schongauer en la pintura gótica aragonesa, nuevas reflexiones, „Artigrama” 2017, nr 32, s. 41-70. 


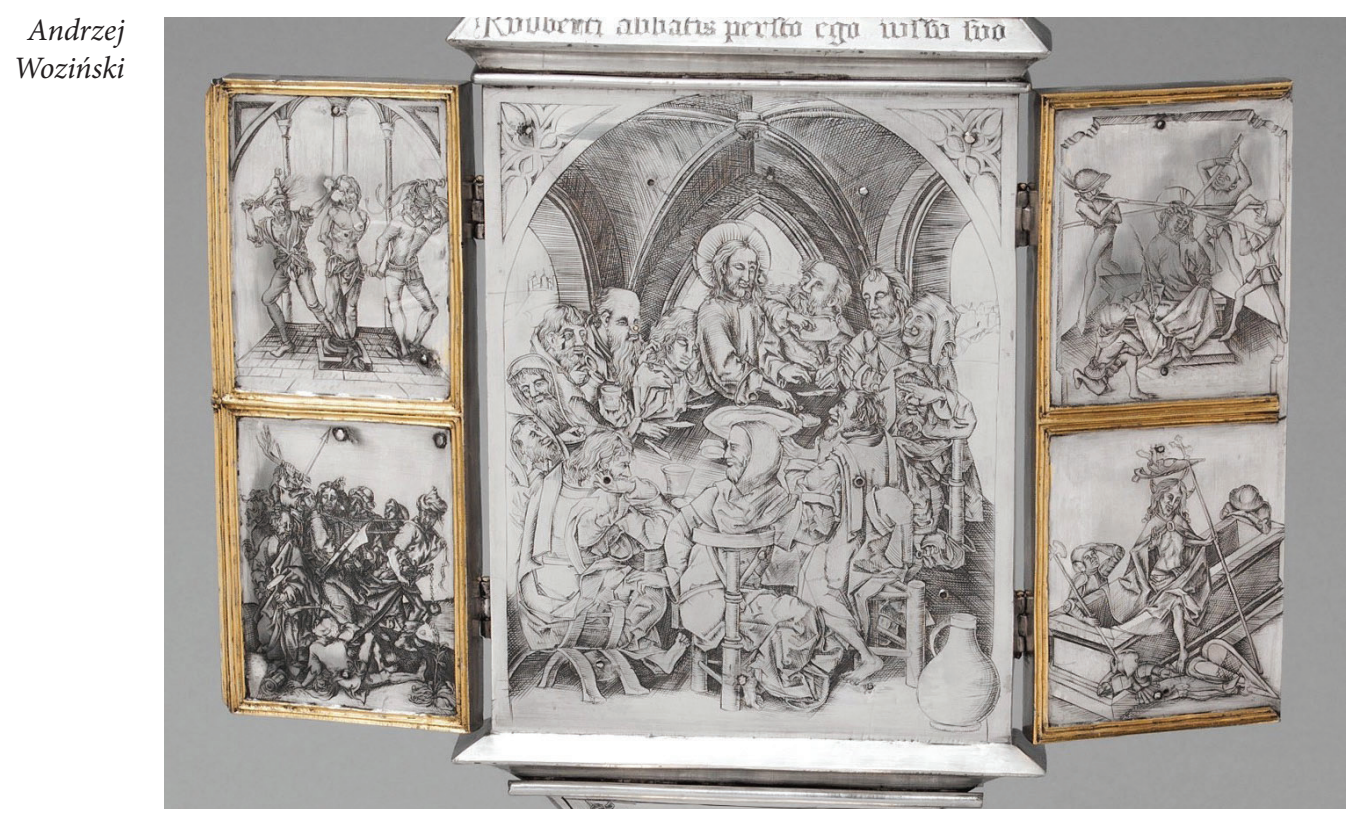

Il. 4. Ostatnia Wieczerza, odwrocie ołtarzyka domowego z Salzburga, 1494, The Metropolitan Museum of Art w Nowym Jorku, fot. ze zbiorów autora

zdobiącym ściany kościoła San Leonardo w Provesano niedaleko Udine ${ }^{62}$. Artysta dość wiernie powtórzył pozy postaci, natomiast nieco inaczej rozmieścił motywy na pierwszym planie i zlokalizował scenę - w narożniku wnętrza u zbiegu dwóch arkad. Datę wykonania fresków Lehrs uznał za terminus ante quem powstania sztychu. Da Tolmezzo wykorzystał w nich również inną rycinę Niderlandczyka - Pojmanie Chrystusa, natomiast pozostałe sceny inspirowane są grafikami Schongauera ${ }^{63}$. Freski w Provesano stanowią jeden z najwcześniejszych przykładów recepcji niderlandzkiej grafiki we Włoszech ${ }^{64}$.

Kolejnym przykładem będą malowidła tego samego twórcy przedstawiające cykl pasyjny, datowane mniej więcej na ten sam okres, znajdujące się w kościele San Gregorio w Aviano, w prowincji Pordenone ${ }^{65}$. Tu również Gianfrancesco odwołał się, choć wybiórczo, do sztychu niderlandzkiego (il. 5). Nie całkiem dokładnymi cytatami są trzej apostołowie pośrodku pierwszego planu, do których malarz dodał z prawej strony ucznia wycierającego nos, wziętego

62 Lehrs, Geschichte und kritischer Katalog..., Bd. 7, s. 181.

63 Remigio Marini, Arte veneta e arte nordica in Gian Francesco da Tolmezzo, „Emporium. Parole e figure" 1955, nr 730, s. 163-166.

64 Veldman, Images for the Eye..., s. 22.

65 Caterina Furlan, „Io depentore son e non sarò...”. Riflessioni sulla tarda attività di Gianfrancesco da Tolmezzo [w:] Gianfrancesco da Tolmezzo e il restauro della pala di Santa Giuliana in Castello di Aviano [katalog wystawy], chiesa di San Francesco, Pordenone, Pordenone 1991, s. $10 \mathrm{n}$. 


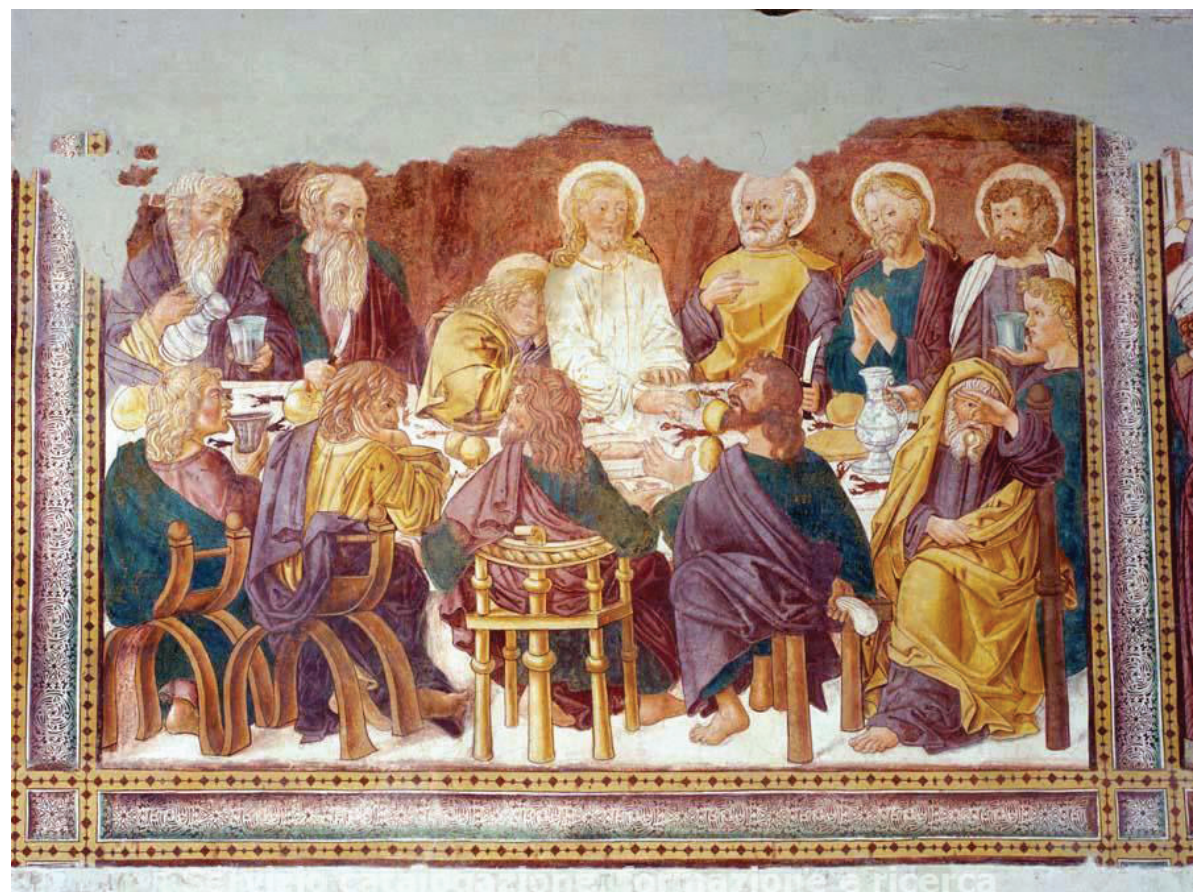

Co wspólnego ma Wniebowzięcie Marii...

Il. 5. Gianfrancesco da Tolmezzo, Ostatnia Wieczerza, około 1496, San Gregorio w Aviano, fot. ze zbiorów autora

z drugiego planu ryciny. Reszta malowidła różni się od sztychu zasadniczo, przede wszystkim inaczej zbudowana jest kompozycja, którą artysta spłycił i rozciągnął wszerz.

Kolejny przykład to kwatera ze zdekompletowanego retabulum pochodzącego prawdopodobnie z klasztoru San Francesco di Stampace w Cagliari na Sardynii z 1497 r. (Cagliari, Pinacoteca Nazionale, il. 6). Wcześniej uważano, że retabulum znajdowało się w kościele Matki Boskiej Anielskiej w Porcjunkuli koło Asyżu. Dzieło przypisywane jest anonimowi wykształconemu w Hiszpanii (Kastylia), określanemu jako Maestro di Castelsardo ${ }^{66}$. Kazanie św. Francisz$k a$, podobnie jak obraz poznański, stanowi kombinację motywów wziętych z grafik ukazujących inne tematy. Zaczerpnięte $\mathrm{z}$ nich postaci straciły pierwotną tożsamość - zyskały nową. Wśród słuchaczy świętego rozpoznajemy apostoła siedzącego na krześle Dantego oraz flankujących go dwóch innych uczniów Chrystusa, pochodzących z miedziorytu Mistrza IAM z Zwolle ${ }^{67}$. Mężczyzna

66 Marco Antonio Scanu, Il Retablo della Porziuncola del Maestro di Castelsardo nella Pinacoteca Nazionale di Cagliari: Rilettura delle vicende e dell'iconografia, „Biblioteca Francescana Sarda" 2012/2013, vol. 15, s. 113-182 (tamże wcześniejsza literatura).

${ }^{67}$ Zależność kwatery z Cagliari od sztychu Mistrza IAM z Zwolle ustalił Simone Mereu, Osservazioni sull'opera del Maestro di Castelsardo, „Studi Sardi” 2000, vol. 32, s. 372, 382; zob. też Scanu, Il Retablo della Porziuncola..., s. 122, il. IIIa, V. 


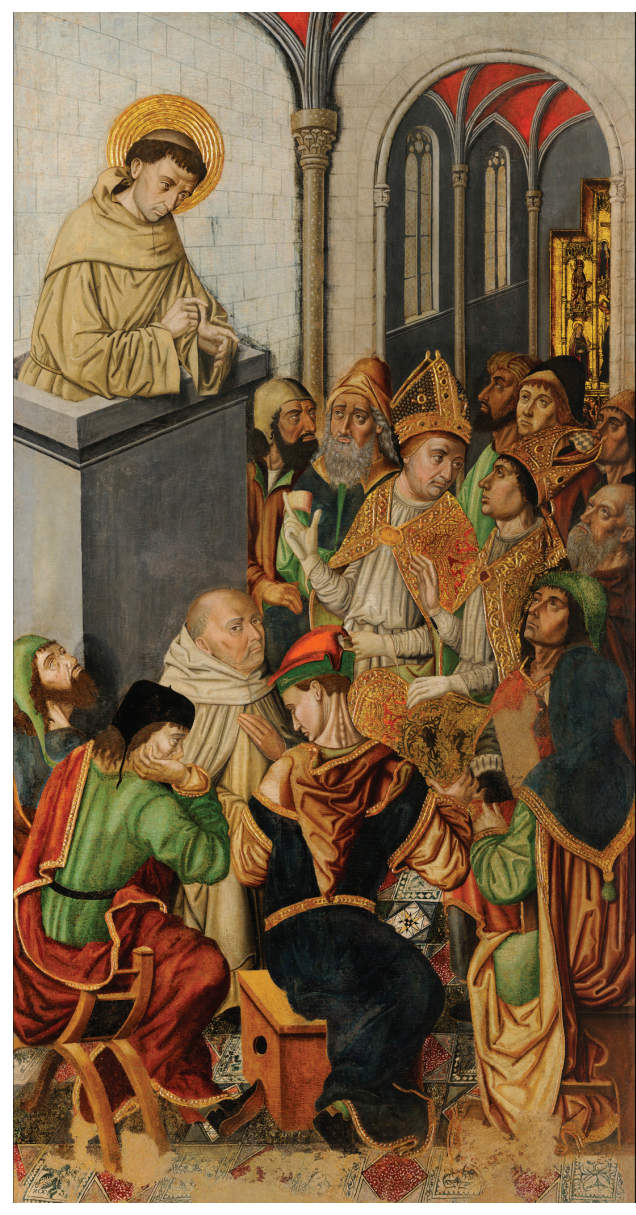

Il. 6. Maestro di Castelsardo, Kazanie św.

Franciszka, kwatera z retabulum kościoła San Francesco di Stampace w Cagliari, około 1497, Pinacoteca Nazionale w Cagliari, fot. ze zbiorów autora

w kapturze $\mathrm{z}$ wyciągniętą lewą ręką to cytat z grafiki Izraela van Meckenem Wieczerza w Emaus. Dwaj mężczyźni w głębi obrazu z lewej strony stanowią z kolei parafrazę postaci usytuowanych po lewej stronie tronu w grafice Sad Salomona autorstwa Mistrza $\mathrm{FVB}^{68}$. Dalsze wzorce dla kilku motywów w obrazie wskazał Marco Antonio Scanu ${ }^{69}$.

Zajmujący nas sztych znany był w Kastylii, o czym świadczy kwatera z Ostatnia Wieczerza z retabulum (około 1480-1488 i po 1493), wykonanego przez Fernando Gallego i Maestro Bartolomé wespół z warsztatem z katedry w Rodrigo w prowincji Salamanka (Tucson, The University of Arizona Museum of Art, il. 7) ${ }^{70}$. Na obrazie powtórzono $-\mathrm{z}$ drobnymi zmianami - pozy apostołów, zrezygnowano $\mathrm{z}$ akcesoriów na pierwszym planie, całkowicie zmieniono wnętrze, silniej wyeksponowano Zbawiciela, ustawiając go frontalnie na osi i kierując jego wzrok na widza. Ponadto nadano scenie zdecydowany wydźwięk eucharystyczny - poprzez umieszczenie w centrum obrazu kielicha, z którego Chrystus wyciąga hostię.

W kontekście związków z niderlandzkim sztychem nie rozpatrywano jak dotąd, o ile mi wiadomo, drzeworytu z Ostatnia Wieczerza, zamieszczonego we wspomnianym już kobergerowskim wydaniu Schatzbehalter oder Schrein der wahren Reichtümer... Stephana Fridolina (il. 8) ${ }^{71}$. Podobieństwa zauważamy u trzech apostołów na pierwszym planie, przy czym obie grupy ukazano w lustrzanym odbiciu. W obu przypadkach widzimy apostoła podpierającego il. VI-VII.

$69 \quad$ Ibidem, s. 122 n., il. VIII, X-XIV.

70 Fernando Gallego and his Workshop: The Altarpiece from Ciudad Rodrigo. Paintings from the Collection of the University of Arizona Museum of Art [katalog wystawy], ed. Amanda W. Dotseth, Barbara C. Anderson, Mark A. Roglán, Dallas 2008, s. 100, 318-319, kat. 19 (tamże wcześniejsza literatura).

71 Getty Research Institute, sygn. INCUN 84B, il. 47, https://archive.org/details/ gri_33125008960557/page/n13/mode/2up [dostęp: 13.04.2020]. 


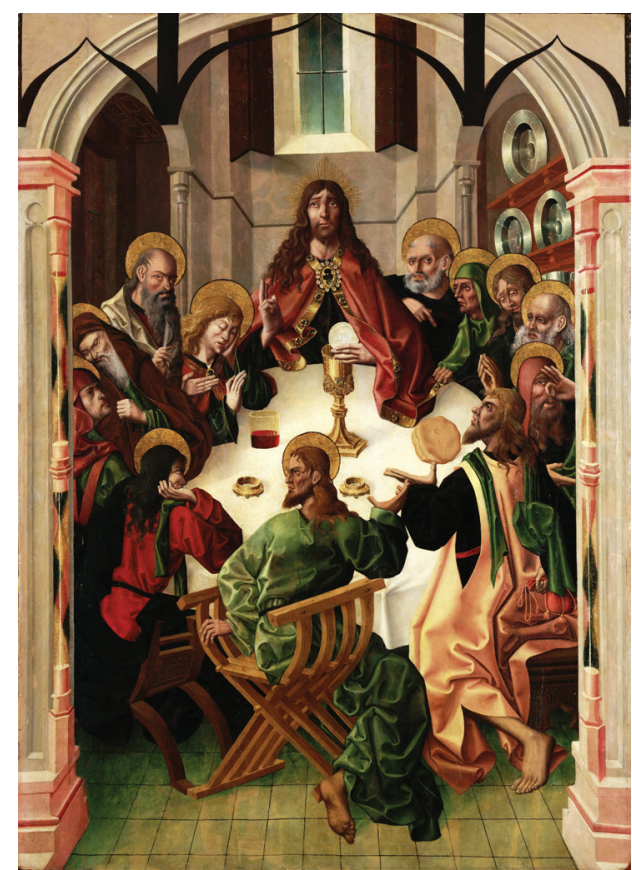

Il. 7. Fernando Gallego, Maestro Bartolomé oraz warsztat, Ostatnia Wieczerza, kwatera $\mathrm{z}$ retabulum katedry w Rodrigo, około 1480-1488 i po 1493, The University of Arizona Museum of Art w Tuscon, fot. ze zbiorów autora

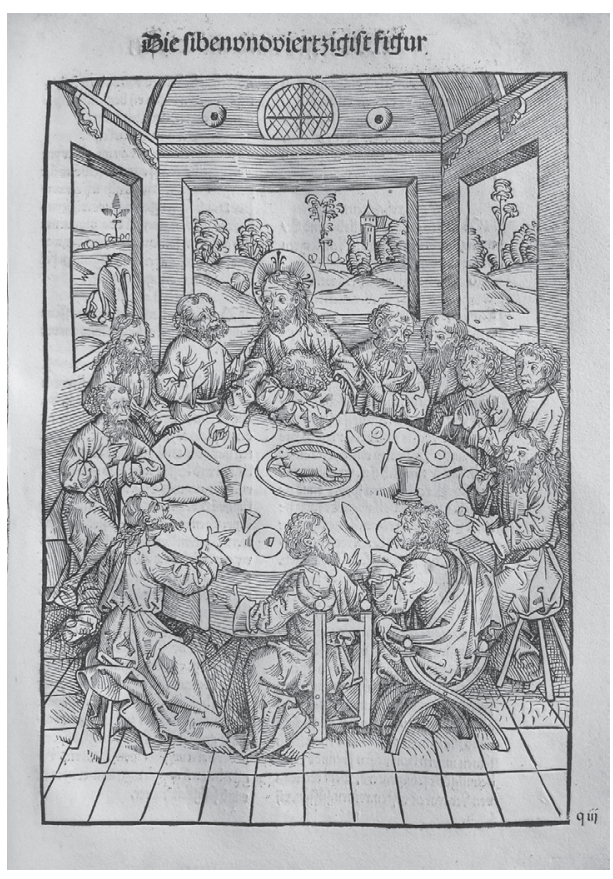

Il. 8. Michael Wolgemut i Wilhelm Pleydenwurff, Ostatnia Wieczerza, 1491, repr. za: Stephan Fridolin, Schatzbehalter oder Schrein der wahren Reichtümer..., wyd. Anton Koberger, Norymberga

głowę dłonią i siedzącego na krześle Dantego (choć inaczej ustawionym); apostoła ukazanego od tyłu, silnie gestykulującego, zwracającego głowę ku temu pierwszemu, oraz Judasza $\mathrm{z}$ uniesioną głową, który wyciąga rękę ponad stołem, drugą zaś chowa za plecami, trzymając w niej sakiewkę. Mimo różnic $\mathrm{w}$ detalach podobieństwo tych postaci wydaje się nieprzypadkowe. W podobny sposób ukształtowano też wnętrze wieczernika - ma trójdzielną strukturę; przezrocza otwierają się na pejzaż lub na sceny rozgrywające się na dalekim planie. Pozostałe partie zostały rozwiązane odmiennie. Trudno rozstrzygnąć, która z grafik była pierwowzorem. Nie można też wykluczyć, że istniało dzieło, do którego obie nawiązywały lub były pomiędzy nimi jakieś ogniwa pośrednie.

Przedstawione tutaj przykłady recepcji niderlandzkiego sztychu stanowią jeszcze jedno potwierdzenie istnienia zauważonego już dawno temu i wielokrotnie analizowanego zjawiska przenikania sztuki Północy na tereny śródziemnomorskie. Zasięg oddziaływania tego wzoru, obejmujący północną Francję, Wielkopolskę, Austrię, południowe Niemcy (?), północne Włochy, Sardynię i Kastylię, pokazuje, jak bardzo uniwersalny charakter miała, mimo wszelkich różnic regionalnych, kultura wizualna tamtego okresu. 


\section{Bibliografia}

Barnet Peter, Wu Nancy Y., The Cloisters: Medieval Art and Architecture [katalog wystawy], The Metropolitan Museum of Art, New York-New Haven 2005.

Białłowicz-Krygierowa Zofia, Galeria Sztuki Średniowiecznej [w:] Muzeum Narodowe w Poznaniu. Przewodnik, Poznań 1977, s. 5-22.

Boesten-Stengel Albert, Joos von Cleves Reinhold-Altar. Masaccios Schatten erreichen via Antwerpen Danzig [w:] Die Danziger Marienkirche. Der Bau und ihre Ausstattung im europäischen Kontext, red. Tomasz Torbus, Gerhard Weilandt [w przygotowaniu].

Dębicki Jacek, Obraz Wniebowzięcie Panny Marii z kościoła Ojców Bernardynów w Warcie - nieodczytane dotąd arcydzieło krakowskiej ikonografii [w:] Visibilia et Invisibilia w sztuce średniowiecza. Księga poświęcona pamięci profesor Kingi Szczepkowskiej-Naliwajek, red. Artur Badach, Monika Janiszewska, Monika Tarkowska, Warszawa 2009, s. 257-286.

Dubbe Berend, Is Johan van den Mynnesten de Meester van Zwolle?, „Bulletin van het Rijksmuseum" 1970, vol. 18, s. 55-65.

Ewangelie apokryficzne. Apokryfy Nowego Testamentu, red. Marek Starowieyski, Lublin 1986.

Fernando Gallego and his Workshop: The Altarpiece from Ciudad Rodrigo: Paintings from the Collection of the University of Arizona Museum of Art, ed. Amanda W. Dotseth, Barbara C. Anderson, Mark A. Roglán, Dallas 2008.

Filedt Kok Jan Piet, Master IAM of Zwoll the personality of a designer and engraver [w:] Festschrift to Erik Fischer. European drawings from six centuries, ed. Villads Villadsen, Copenhagen 1990, s. 341-356.

Freus Paweł, Małopolski typ Wniebowzięcia Marii [w:] Visibilia et Invisibilia w sztuce średniowiecza. Księga poświęcona pamięci profesor Kingi Szczepkowskiej-Naliwajek, red. Artur Badach, Monika Janiszewska, Monika Tarkowska, Warszawa 2009, s. 239-256.

Furlan Caterina, "Io depentore son e non sarò...". Riflessioni sulla tarda attività di Gianfrancesco da Tolmezzo [w:] Gianfrancesco da Tolmezzo e il restauro della pala di Santa Giuliana in Castello di Aviano, catalogo della mostra (Pordenone, chiesa di San Francesco), Pordenone 1991, s. 9-26.

Gadomski Jerzy, Gotyckie malarstwo tablicowe Małopolski 1460-1500, Warszawa 1988. Gadomski Jerzy, Jan Wielki. Krakowski malarz z drugiej połowy wieku XV, Kraków 2005. Heusinger Christian von, Meister IAM von Zwolle [w:] De Gruyter Allgemeines KünstlerLexikon. Die Bildenden Künstler aller Zeiten und Völker, Hg. Andreas von Beyer, Bénédice Savoy, Wolfgang Tegethoff, Bd. 88, Matijin-Meixner, Berlin-Boston 2016, s. $409-410$.

Karłowska-Kamzowa Alicja, Malarstwo (Sztuka gotycka) [w:] Dzieje Wielkopolski, t. 1 (do roku 1793), red. Jerzy Topolski, Poznań 1969, s. 422-434.

Labuda Adam S., Malarstwo tablicowe w Wielkopolsce, na Kujawach i Mazowszu [w:] Malarstwo gotyckie w Polsce, t. 1, Synteza, red. Adam S. Labuda, Krystyna Secomska, Warszawa 2004, s. 311-332.

Labuda Adam S., Malarstwo tablicowe w Wielkopolsce. Szkice do dziejów ksztattowania się środowiska artystycznego na przełomie średniowiecza i czasów nowych [w:] Malarstwo 
gotyckie w Wielkopolsce, Studia o dziełach i ludziach, red. Adam S. Labuda, Poznań 1994, s. 59-120.

Leeflang Micha, Joos van Cleve. A Sixteenth-century Antwerp Artist and His Workshop, Turnhout 2015 (Me Fecit, 8).

Leeflang Micha, The Saint Reinhold Altarpiece by Joos van Cleve and his Workshop: New Insights into the influence of Albrecht Durer on the Working Process [w:] Making \& Marketing: Studies of the Painting Process in Fifteenth-and Sixteenth-Century Netherlandish Workshops, ed. Molly Faries, Turnhout 2006, s. 15-42.

Marini Remigio, Arte veneta e arte nordica in Gian Francesco da Tolmezzo, „Emporium. Parole e figure" 1955, vol. 59, nr 10, s. 157-168.

Mayr-Harting Ursula, Early Netherlandish Engraving c. 1440-1540 [katalog wystawy], Ashmolean Museum, Oxford 1997.

Mereu Simone, Osservazioni sull'opera del Maestro di Castelsardo, „Studi Sardi” 2000, vol. 32, s. 367-384.

Pfeil Daniela Gräfin von, Jörg Stocker - ein verkannter Maler aus Ulm [w:] Meisterwerke massenhaft. Die Bildhauerwerkstatt des Niklaus Weckmann und die Malerei in Ulm um 1500 [katalog wystawy], Hg. Gerhard von Weiland, Ausstellungskatalog vom Württembergischen Landesmuseum Stuttgart, Stuttgart 1993, s. 199-210.

Scanu Marco Antonio, Il Retablo della Porziuncola del Maestro di Castelsardo nella Pinacoteca Nazionale di Cagliari: Rilettura delle vicende e dell'iconografia, "Biblioteca Francescana Sarda" 2013, vol. 15, s. 113-182.

Secomska Krystyna, Wniebowzięcie w kościele parafialnym $w$ Warcie. Analiza ikonograficzna [w:] Malarstwo gotyckie w Wielkopolsce. Studia o dziełach i ludziach, red. Adam S. Labuda, Poznań 1994, s. 121-162.

Sławska Aniela, Muzeum Narodowe w Poznaniu. Przewodnik, Poznań 1971.

Soćko Adam, Wniebowzięcie Najświętszej Marii Panny [w:] Ars una species mille. 150 dzieł na 150-lecie Muzeum Narodowego w Poznaniu ze zbiorów Poznańskiego Towarzystwa Przyjaciót Nauk [katalog wystawy], red. Dorota Suchocka, Muzeum Narodowe w Poznaniu, Poznań 2007, s. 50-51.

Szmydki Ryszard, Retables anversois en Pologne. Contribution à l'étude des rapports artistiques entre les anciens Pays-Bas Méridionaux et la région de Gdańsk au début du XVIe siècle, Brussel 1986.

Veldman Ilja, Images for the Eye and Soul: Function and Meaning in Netherlandish Prints (1450-1650), Leiden 2006.

Wetesko Leszek, Maior Polonia Sacra. Sztuka sakralna w średniowiecznej Wielkopolsce. Historia pewnych tematów [katalog wystawy], Muzeum Początków Państwa Polskiego w Gnieźnie, Gniezno 1997.

Woziński Andrzej, Galeria sztuki średniowiecznej. Przewodnik, Poznań 1990.

Zbiory Poznańskiego Towarzystwa Przyjaciót Nauk w Muzeum Narodowym w Poznaniu [katalog wystawy], red. Magdalena Warkoczewska, Poznań 1982.
Co wspólnego ma Wniebowzięcie Marii... 
What Does the Assumption of Virgin Mary Have in Common with the Last Supper, or on the Origin of the Form and Iconography of the Late Gothic Panel Painting from the Collection of the National Museum in Poznań, or on the Late Medieval Methods of Panel Painting with a Use of Prints, or on Northern Art Diffusion into Southern Europe

The late medieval panel painting of the Assumption of Virgin Mary from the Collection of the National Museum in Poznan was most likely created in Greater Poland (Wielkopolska), probably in Poznan, in the early $16^{\text {th }}$ century. Scholars have pointed out the connection of its iconography with several other art pieces from the area of Greater Poland. In the light of these findings, our painting seemed to be traditional in the terms of form, as well as of content. This paper shows that some formal solutions and motifs used in the painting from Poznan differ from a typical iconographic practice, and it has only partial coverage in literary sources. The Apostles' behaviour not fully corresponding to the subject and the chair in which an unidentified Apostle is sitting in a strangely complicated pose by the sarcophagus are the exceptional traits of the Poznan painting. The reason for their presence is the fact that the painter quoted a large part of the copperplate engraving of the Netherlandish Master IAM of Zwolle on a completely different subject: the Last Supper. The painter repeated selected elements quite accurately, without trying too much to adopt them to the new context. The Poznan painting is one of the countless examples of the use of prints as a pattern in the late medieval workshop practice. But at the same time, it belongs to the smaller in number works that were created in a more sophisticated way, through a compilation of motifs taken from various sources, combined with iconographic transformations. The paintings of Jörg Stoker, active in Ulm, and the prominent Antwerp artist Joos van Cleve analysed in the paper, are the examples of the application of a similar creative procedure. The last part of the text is devoted to the reception of the copperplate engraving by Master IAM of Zwolle, which determined so markedly the form and iconography of the painting at the National Museum in Poznań. The range of impact of this pattern, including Northern France, Greater Poland, Austria, Southern Germany (?), Northern Italy, Sardinia and Castilla, illustrates how universal, despite all the regional differences, the visual culture of Latin Europe was at the time. 